\title{
PERANAN IBU RUMAH TANGGA DALAM PERLINDUNGAN KONSUMEN
}

\author{
Ni Ketut Sari Adnyani \\ Jurusan Ilmu Hukum Fakultas Ilmu Sosial \\ Universitas Pendidikan Ganesha, Singaraja. \\ E-mail: sariadnyani@yahoo.co.id
}

\begin{abstract}
ABSTRAK
Tujuan penelitian ini adalah: untuk mengetahui keamanan jasa layanan produsen terhadap konsumen secara transfaran; standar produk yang dipasarkan dapat dikonsumsi publik secara aman dan nyaman dari segi kebersihan dan standarisasi kesehatan. Pemahaman positif lainnya yang diperoleh, kegiatan penyeleksian produk, diantaranya meliputi: dapat memberikan bekal wawasan tentang pentingnya penjaminan dan perlindungan konsumen dalam kegiatan distribusi produk produksi di tingkat pedesaan khususnya terhadap para Ibu rumah tangga di desa Tianyar, diantaranya yaitu: (1) Mengidentifikasi jenis kasus penipuan produsen barang dan jasa terhadap konsumen di Desa Tianyar Kecamatan Kubu Kabupaten Karangasem; Memberikan gambaran mengenai tingkat perilaku konsumen di Desa Tianyar Kecamatan Kubu Kabupaten Karangasem sebelum disasar sosialisasi UU perlindungan konsumen; (3) Mengetahui pengaruh faktor-faktor sosial ekonomi terhadap kecurangan perilaku produsen di Desa Tianyar.

Penelitian ini adalah bersifat yuridis normatif dengan kajian tindak lanjut sosialisasi UU No. 8 Tahun 1999 tentang Perlindungan Konsumen. Subjek penelitian ini adalah informan yang dinilai berkompeten dengan penelitian. Bahan Hukum Primer yaitu terkait dengan informasi yang dibutuhkan dari responden, yaitu dengan Staf Pemerintah Daerah Kabupaten Karangasem Bagian Hukum, Aparatur Pemerintah Desa Tianyar, Perwakilan Staf Bidang Kesehatan Masyarakat dari Puskesmas Kubu II, Ibu Rumah Tangga (perwakilan dari peserta sosialisasi UU Perlindungan Konsumen), Warga Masyarakat Desa Tianyar selaku pengguna jasa pelayanan produk konsumsi keluarga. Bahan hukum sekundernya adalah melakukan inventarisasi bahan hukum yang ada relevansinya dengan perlindungan konsumen.

Hasil penelitian ini berpengaruh terhadap meningkatnya pemahaman Ibu rumah tangga di Desa Tianyar tentang UU Perlindungan Konsumen No. 8 Tahun 1999 yang menjadi dasar dalam melakukan antisipasi terhadap praktek kecurangan produsen, termasuk dalam peredaran produk yang tidak memenuhi standarisasi kelayakan produksi. Ibu rumah tangga menjadi memperoleh pemahaman untuk mengetahui jenis peredaran produk palsu atau oplosan yang dahulunya banyak dikonsumsi oleh masyarakat Desa Tianyar Kecamatan Kubu.
\end{abstract}

Kata Kunci : Ibu Rumah Tangga, Kebutuhan, Kelayakan, Keluarga, Perlindungan Konsumen, Produk, Seleksi. 


\begin{abstract}
The purpose of this study is: to find out the manufacturer of the security services are transparent to the consumer; standard products that are marketed to the public consumed safely and comfortably in terms of cleanliness and health standards. Another positive understanding gained, product screening activities, among others include: to provide insight into the importance of the provision of the guarantee and protection of consumers in the production of the product distribution activities at a local level, especially to housewives in the village Tianyar, such as: (1) Identify the types of cases fraud producers of goods and services to consumers in Tianyar Village, Karangasem regency, (2) Provides an overview of consumer behavior at the Tianyar village level, Karangasem regency before the targeted dissemination of consumer protection laws, (3) Determine the influence of socioeconomic factors on cheating Tianyar producer behavior in the village.

This study is a normative juridical follow-up study of socialization Law. 8 of 1999 on Consumer Protection which has been implemented in accordance with the conditions applicable in the field. The subjects in this research is a competence informants . Primary Legal Materials is legal materials obtained directly from informants, like, associated with the required information from the respondents, namely the staff of Local Government Law Section of Karangasem regency, Tianyar Village Government Reform, Public Health Field Staff Representative of PHC Kubu II, Mother Household (representative of the participant socialization Consumer Protection Act), Public Citizen Tianyar village as service users family consumer products. Secondary legal materials is to conduct an inventory of legal materials by reading or reference books or journal literature supporting the law relating to the research topic.

The results of this study obtain great results that understanding of housewives in the village Tianyar into the Consumer Protection Act No. understanding. 8, 1999 that became the basis of the fraudulent practices of manufacturers, including the circulation of products which do not meet the eligibility standards of production. Homemakers to gain an understanding as to what kind circulation of counterfeit or adulterated products which used widely consumed by the people of Tianyar village.
\end{abstract}

Keywords : Housewife, Necessity, Feasibility, Families, Consumer Protection, Product, Selection.

\section{Pendahuluan}

Diundangkannya UU No. 8 Tahun 1999 Tentang Perlindungan Konsumen ini adalah untuk mengatur prilaku pelaku usaha dengan tujuan agar konsumen dapat terlindung secara hukum. sehingga upaya untuk melindungi kepentingan konsumen yang dilakukan melalui perangkat hukum diharapkan mampu menciptakan norma hukum perlindungan konsumen. Selain itu diharapkan dapat menumbuh kembangkan sikap usaha yang bertanggung jawab, serta peningkatkan harkat dan martabat konsumen (Darwis, 2010: 23) 
Namun pada kenyataannya dalam penerapan UU No. 8 Tahun 1999 Tentang Perlindungan Konsumen terjadi kesenjangan antara konsep dengan kondisi di lapangan. Permasalahan prilaku produsen berawal dari ada atau tidaknya kesadaran dari masyarakat konsumen untuk peka menyeleksi jenis produk bahan makanan dan minuman yang dikonsumsinya. Selain dipengaruhi oleh keadaan pengetahuan konsumen yang masih rendah, juga didorong oleh berbagai faktor sosial ekonomi para pelaku ekonomi itu sendiri, termasuk ada atau tidaknya norma-norma sosial yang berlaku di lingkungannya yang mengatur agar kehidupan berjalan selaras dan seimbang seperti salah satu wujudnya adalah dengan penyediaan pelayanan jasa perlindungan konsumen kepada para pembeli.

Kajian penelitian ini terfokus pada perlindungan konsumen, yaitu meningkatkan pemahaman akan jaminan keselamatan bagi konsumen, karena setiap pemakai barang dan/atau jasa yang tersedia dalam masyarakat, baik itu bagi kepetingan diri sendiri, keluarga, orang lain maupun mahluk hidup lain berhak mendapatkan perlindungan hukum. Kedudukan Ibu rumah tangga sebagai pelanggan setia segala macam jenis produk makanan dan minuman yang beredar di pasaran berhak mendapatkan perlindungan hukum dari segala perbuatan yang merugikan konsumen yang dilakukan oleh para produsen nakal yang cenderung berbuat curang dalam memasarkan produknya.

Fakta yang selama ini terjadi bahwa keistimewaan perlakuan dapat dinikmati para konsumen adalah dapat mengkonsumsi jenis produk makanan dan minuman dengan tarif miring atau lebih murah akan tetapi efek sampingnya justru dengan penawaran harga murah tersebut para Ibu rumah tangga atau warga masyarakat pada umumnya lengah karena cenderung dihadapkan pada persoalan banyaknya produk barang berupa makanan dan minuman yang tidak mencantumkan standarisasi dari BPOM termasuk masa kadaluarsa barang tersebut boleh dikonsumsi. Hal yang baru dapat diapresiasi dengan manfaat dari kegiatan penelitian ini adalah diprioritaskannya kepentingan konsumen dalam penilaian terhadap Larangan Praktek Monopoli dan Persaingan Usaha Tidak Sehat.

Keberlanjutan terhadap program sosialisasi telah dirancang kegiatan penelitian sehingga hasil penelitian tersebut dapat dijadikan media komunikasi publik yang dapat menjembatani kebutuhan hukum masyarakat khususnya bagi warga masyarakat atau konsumen yang dalam hal ini diwakili dari kalangan Ibu rumah tangga dalam menjalankan kegiatan ekonomi secara aman dan terkendali untuk memberikan pelayanan jasa kepada para konsumen lokal.

Para produsen nakal yang cenderung menyalahi kode etik tata cara menjalankan usaha yang benar harus dicegah keberadaannya bahkan jika masih dijumpai keberadaannya di lapangan instansi yang berwenang seperti BPOM secara berkala dimintakan kesediaannya dalam menyidak pasar-pasar tradisional yang dinilai 
rawan sebagai tempat peredaran barang palsu atau imitasi, oplosan dan mengandung bahan kimia berbahaya yang dapat mengancam keselamatan jiwa para konsumen. Ketidak berdayaan masyarakat dalam menghadapi perilaku curang para produsen tersebut jelas sangat merugikan, dimana produsen berlindung pada perjanjian baku yang telah disepakati dan ditandatangani kedu belah pihak. Sehingga konsumen dijadikan sebagai obyek bisnis untuk meningkatkan keuntungan para produsen.

Perlindungan Konsumen pada dasarnya merupakan bagian penting dalam ekonomi pasar (laissez faire). Di pasar bebas, para pelaku usaha menawarkan produk dan jasa dengan tujuan mencari keuntungan di satu sisi, berhadapan dengan para pembeli dan konsumen yang ingin memperoleh barang dan atau jasa yang murah dan aman di sisi lain. Tetapi di dalam pasar bebas, kedua pihak itu tidak memiliki kekuatan yang sama. Posisi pihak pelaku usaha jauh lebih kuat ketimbang para konsumen yang merupakan perorangan, karena penguasaan informasi tentang produk sepenuhnya ada pada produsen. Sehingga posisi para konsumen sebenarnya amat rentan untuk dieksploitasi. Hanya dengan seperangkat aturan hukum atau perundang-undangan yang ditetapkan oleh negara, ketimpangan informasi tersebut dapat diatasi. Sehingga keberadaan peraturan perundang-undangan yang dibuat oleh negara tersebut, benar-benar dapat memberikan perlindungan terhadap konsumen (Darwis, 2010: 17).

Beberapa temuan di atas,
memberikan indikasi bahwa
perlindungan konsumen melalui
peran Ibu rumah tangga dalam
menyeleksi produk yang akan
dikonsumsi sangat penting. Namun
permasalahan di lapangan
menunjukkan
pemahama Ibu rumah tangga dalam perlindungan konsumen menyebabkan terjadi permasalahan kecurangan perilaku produsen belum secara optimal mampu diidentifikasi keberadaannya oleh para Ibu rumah tangga. Hal ini disebabkan oleh karena adanya beberapa kesulitan yang ditemui oleh Ibu rumah tangga di Tianyar dalam memahami perlindungan konsumen. Oleh karena itu, penelitian ini bertujuan untuk mengidentifikasi kesulitan-kesulitan yang ditemui Ibu rumah tangga di desa Tianyar dalam perlindungan konsumen khususnya dalam mengkonsumsi produk kebutuhan sehari-hari dan mengetahui upayaupaya yang dilakukan untuk pemecahan masalah tersebut.

\section{Metode Penelitian}

Penelitian ini menggunakan pendekatan kualitatif yang dilakukan di desa Tianyar pada Ibu rumah tangga. Pemilihan informan dilakukan dengan metode purposive sampling. Data dikumpulkan dengan menggunakan teknik pengamatan secara langsung (participantobservation), teknik wawancara yang dilakukan adalah wawancara bebas mendalam (indepth interview) dengan pertanyaan-pertanyaan yang sifatnya sistematis.

Data yang diperoleh dalam penelitian, dianalisis secara deskriptif kualitatif dengan tahapan 
dimulai dari reduksi data, penyajian data, dan penarikan simpulan/verifikasi data. Ketiga tahapan ini dilakukan selama proses penelitian berlangsung untuk menentukan konsistensi alur penelitian yang telah dirancang.

Sasaran utama penelitian adalah para Ibu rumah tangga yang diharapkan dapat memberikan pencerahan bagi mereka akan pentingnya jaminan keselamatan dan perlindungan terhadap konsumen. Demikian juga halnya, setelah memperoleh pembekalan melalui kegiatan sosialisasi ini diharapkan para Ibu dapat mendampingi putra-putri mereka dalam menyeleksi jenis produk makanan maupun minuman yang layak dikonsumsi serta memenuhi standar hygiene dan sanitasi.

Fokus kegiatan penelitian ini adalah sebagai salah satu forum untuk menjembatani warga masyarakat yang diwakili oleh kalangan Ibu rumah tangga agar dapat bertukar pikiran terhadap keterlibatan pihak yang bersangkutan dalam identifikasi jenis produk kebutuhan konsumsi keluarga yang dibeli warga. Dialog interaktif dengan para Ibu rumah tangga tersebut bertujuan untuk mengetahui peranan orang tua di dalam melakukan seleksi jenis barang atau jasa dalam kapasitasnya sebagai pengguna rutin barang. Di samping itu, sebagai pihak pendamping pembinaan dan pengarahan terhadap laju perkembangan putraputri mereka dalam mengkonsumsi jajanan, baik di sekolah maupun di luar sekolah. Sehingga masyarakat dalam hal ini Ibu rumah tangga dapat lebih cermat dan berhati-hati dalam menyeleksi barang atau jasa yang akan dikonsumsi.

\section{Pembahasan \\ Peran Ibu Rumah Tangga Desa Tianyar dalam Perlindungan Konsumen}

Mengingat kejadian yang terjadi di lapangan bahwa produsen semakin berani dalam memproduksi barang atau produk ilegal, dipandang perlu dilakukan pencegahan baik secara preventif maupun represif. Oleh karena itu, karena aspek kesehatan warga masyarakat dan jaminan keselamatan mereka penting untuk ditingkatkan keberadaannya demi menciptakan manusia Indonesia seutuhnya dan seluruhnya sesuai dengan amanat Pembukaan UUD 1945, merupakan kewajiban dari Ibu rumah tangga menyeleksi jenis produk konsumsi kebutuhan keluarga agar terhindar dari hal-hal yang tidak inginkan seperti kandungan bahan kimia berbahaya yang teridentifikasi dalam produk makanan yang para anggota keluarga mereka akan konsumsi.

Secara bertahap Ibu rumah tangga di Desa Tianyar juga memahami keselamatan konsumen dari tindakan produsen yang tidak bertanggung jawab perlu dilakukan sehingga masyarakat nantinya cerdas dalam memilih produk yang akan dikonsumsi untuk memenuhi kebutuhan hidup sehari-hari. Termasuk mengajukan layangan keluhan atau pengaduan ke pihak terkait apabila di lapangan terindikasi adanya temuan yang tidak layak untuk jenis produk yang dipasarkan. Berdasarkan rekafitulasi data letak geografis, pertumbuhan penduduk, status 
sosial ekonomi masyarakat serta tingkat pendidikan masyarakat Desa Tianyar, pada dasarnya memang sangat mempengaruhi perkembangan mata pencaharian yang ditekuni oleh para warga di tengah-tengah aktivitas sosial masyarakat. Aspek pemenuhan kesejahteraan masyarakat dari sektor mata pencaharian di bidang perdagangan memberikan peranan cukup dominan bagi masyarakat Desa Tianyar untuk berkiprah dan memenuhi kebutuhan hidup mereka secara berkesinambungan.

Adapun tahapan peran Ibu rumah tangga di Desa Tianyar dalam seleksi jenis produk konsumsi keluarga yang dimulai dari:

1) Tahap persiapan, yang terdiri dari tahap :

(a) persiapan bekal pemahaman sesuai tahuan tentang pembekalan wawasan pengetahuan tentang perlindungan konsumen,

(b) melakukan koordinasi antar Ibu rumah tangga Desa Tianyar Kecamatan Kubu,

(c) menyiapkan mental dan fisik untuk mengevaluasi peredaran produk yang akan diseleksi untuk dibeli,

(d) menyiapkan narasumber yang memiliki kompetensi sesuai dengan target dan tujuan apabila sewaktuwaktu di lapangan dijumpai keluhan melalui wadah kelompok wanita yang beranggotakan para Ibu rumah tangga, dan

(e) menyiapkan jadwal rapat rutin anggota yang sudah terjadwalkan secara efektif,

2) Tahap pelaksanaan, yang terdiri dari :

(a) melakukan seleksi produk konsumsi oleh Ibu rumah tangga di Desa Tianyar Kecamatan Kubu, (b) diskusi terbatas mengenai efek peredaran barang palsu yang tidak sesuai UU Perlindungan Konsumen No. 8 Tahun 1999, dan

3) Tahap evaluasi, yang terdiri dari:

(a) presentasi kesimpulan hasil evaluasi dari para Ibu rumah tangga,

(b) refleksi dan seleksi produk, dan

(c) memberikan penilaian terhadap hasil seleksi yang dilakukan oleh Ibu rumah tangga. 
Secara skematis alur kerja pemecahan masalah dalam kegiatan ini, dapat dijabarkan sebagai berikut:

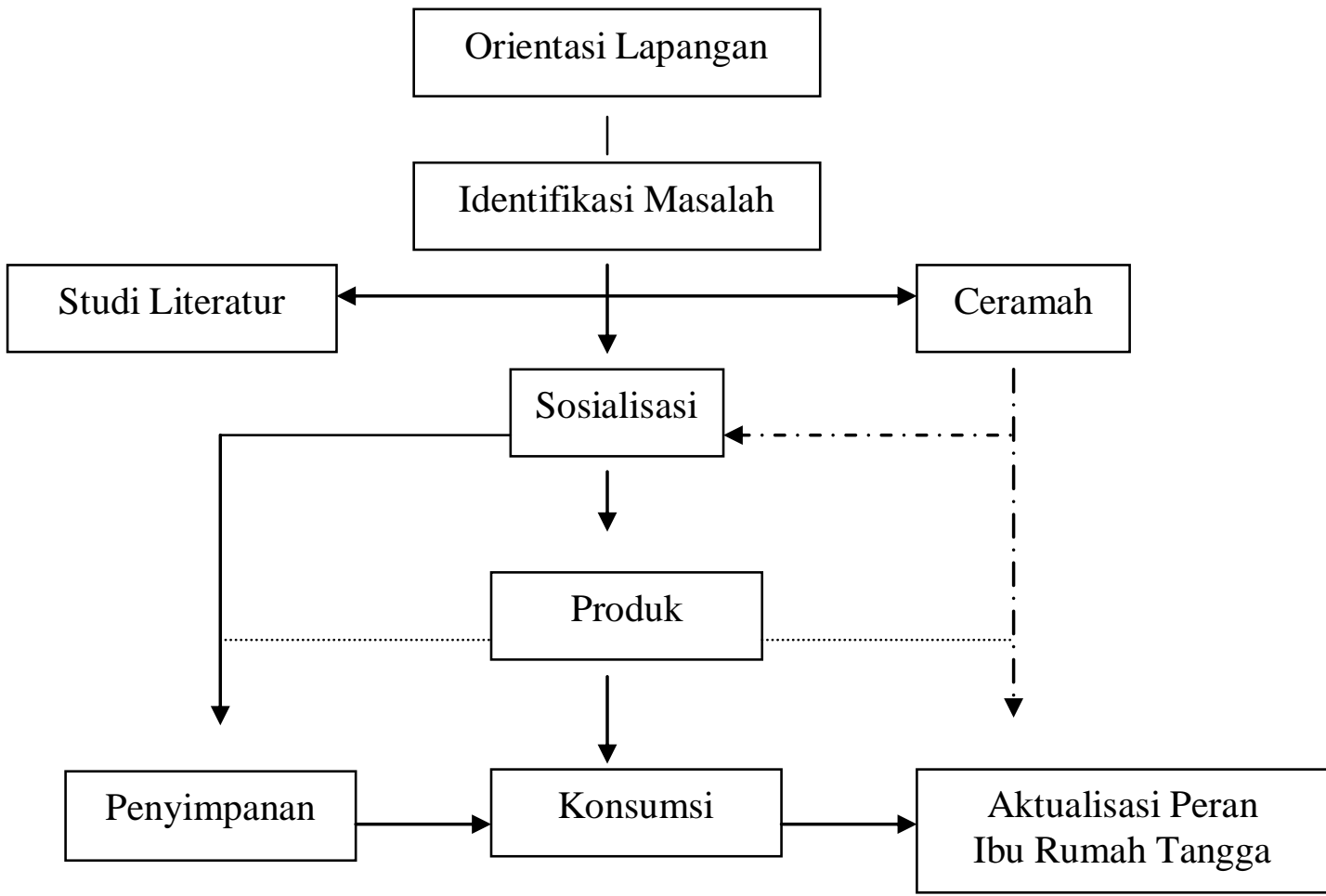

Khalayak sasaran strategis yang dituju dalam penelitian ini adalah Ibu rumah tangga desa Tianyar kecamatan Kubu. Adapun rasionalnya adalah:

(1) Ibu rumah tangga merupakan kelompok masyarakat yang akan melangsungkan transaksi pembelian produk barang untuk konsumsi kebutuhan kehidupan dalam rumah tangga,

(2) Ibu rumah tangga merupakan media penyebarluasan berbagai informasi yang sangat efektif, mengingat mobilitas sosialnya yang sangat tinggi, untuk membina dan mengarahkan putera-puteri dan kepala rumah tangga untu menyeleksi secara selektif setiap jenis produk yang beredar di pasaran dan

(3) Ibu rumah tangga disinyalir akan mampu menjadi penggerak proses tranformasi sosial masyarakat desa Tianyar yang simbolik dengan perlindungan konsumen. Berdasarkan rasional tersebut, maka sasaran yang dipilih dan dipandang cukup visibel untuk diberikan pelatihan adalah Ibu rumah tangga pada masyarakat desa Tianyar kecamatan Kubu yang selama ini sering simbolkan sebagai desa yang konsumtif.

\section{Permasalahan Perlindungan Konsumen yang Dihadapi oleh Ibu Rumah Tangga di Desa Tianyar}

Pada proses pelaksanaan peran seleksi produk oleh Ibu rumah tangga menjadi sangat penting dalam penerapan UU No. 8 Tahun 1999 tentang Perlindungan Konsumen. Awamnya pemahaman akan perlindungan konsumen, 
menyebabkan Ibu rumah tangga sering menjadi korban dalam praktek kecurangan produsen, termasuk dalam peredaran produk yang tidak memenuhi standarisasi kelayakan produksi. Pelaksanaan peran Ibu rumah tangga yang belum optimal dalam menganalisis peredaran produk layak konsumsi juga terekam, bahwa peredaran produk palsu atau oplosan yang banyak dikonsumsi oleh masyarakat Desa Tianyar Kecamatan Kubu lebih banyak hanya dilakukan berdasarkan tanpa memeperhatikan kelayakan kemasan, standarisasi B.POM, batas waktu kelayakan konsumsi, terdapat tidaknya jenis kandungan bahan kimia berbahaya dan penggunaan zat pewarna makanan yang layak untuk produk makanan.

Berbagai altematif pemecahan masalah dilakukan untuk menangani masalah dibahas dalam kegiatan dialog interaktif dengan para Ibu rumah tangga di desa Tianyar, adapun hasil identifikasi terhadap permasalahan yang terjadi di lapangan, diantaranya meliputi:

1. Dengan maraknya kasus merebak produk ilegal dan mengandung bahan kimia berbahaya yang beredar di pasaran dengan mencari solusi dalam pengadaan kerjasama dengan instansi terkait seperti Perguruan Tinggi melalui pengajuan proposal P2M sehingga realisasi kegiatan pengabdian berupa sosialisasi UU Perlindungan Konsumen dapat terwadahi. Alternatif ini dipilih sebagai suatu media untuk mengkoordinir warga masyarakat Desa Tianyar Kecamatan Kubu Kabupaten Karangasem yang berprofesi sebagai Ibu rumah tangga untuk dimintakan kesediaannya diikutkan dalam kegiatan pelatihan yang dilakukan oleh staf dosen perwakilan dari perguruan tinggi Undiksha.

2. Lemahnya pengetahuan konsumen terhadap kelayakan jenis produk yang dipasarkan sudah terjembatani oleh kegiatan sosialisasi dengan mengusung tema UU Perlindungan Konsumen. Adapun pemilihan altematif ini sampai terpilih untuk menghimpun kerjasama untuk membina dan memberikan bekal pengetahuan kepada para Ibu rumah tangga sehingga bisa bertindak sebagai konsumen yang cerdas dan arif. Pemerintah, lembaga perlindungan konsumen dan konsumen harus dapat saling mendukung satu sama lain, sehingga undang- undang perlindungan konsumen dapat berjalan dengan baik dan sesuai pasal-pasal yang tertera dalam UU No.8 Tahun 1999.

3. Dengan kegiatan mengintensifkan peran Ibu rumah tangga di desa Tianyar dalam Perlindungan Konsumen diharapkan dapat menjembatani kebutuhan hukum Ibu rumah tangga selaku konsumen dalam mengantisipasi kecurangan pemasaran produk ilegal dari produsen nakal di pasaran.

\section{Upaya Pemecahan Masalah Perlindungan Konsumen oleh Ibu Rumah Tangga di Desa Tianyar}

Penelitian ini merupakan program penelitian yang bersifat aktual dalam rangka peningkatan pengetahuan dan wawasan Ibu rumah tangga di Desa Tianyar Kecamaan Kubu dalam memahami hukum perlindungan konsumen (UU No. 8 Tahun 1999) dengan langkah 
sosialisasi. Untuk kepentingan pencapaian tujuan program ini, maka rancangan yang dipandang sesuai untuk dikembangkan adalah "RRA dan PRA" (rural rapid appraisal dan participant rapid appraisal). Di dalam pelaksanaannya, program ini akan mengacu pada pola sinergis antara tenaga pakar dan praktisi dari Universitas Pendidikan Ganesha dengan kalangan birokrasi dan administrasi pemerintah Kecamatan Kubu, khususnya pihak Puskesmas Kubu. Di sisi lain, penelitian ini juga diarahkan pada terciptanya iklim kerjasama yag kolaboratif dan demokratis dalam dimensi mutualis antara dunia perguruan tinggi dengan masyarakat secara luas di bawah koordinasi pemerintah desa setempat, khususnya dalam rangka meningkatkan pengetahuan dan wawasan generasi Ibu rumah tangga Desa Tianyar Kecamatan Kubu secara cepat namun berkualitas bagi kepentingan pembangunan masyarakat setempat. Berdasarkan rasional tersebut, maka program ini merupakan sebuah langkah inovatif dalam kaitannya dengan dharma ketiga perguruan tinggi.

Kriteria dan indikator pencapaian tujuan dan tolak ukur yang digunakan untuk menjastifikasi tingkat keberhasilan peran Ibu rumah tangga dalam seleksi produk kebutuhan, dapat diuraikan pada tabel berikut :

Tabel 01. Indikator Keberhasilan Kegiatan

\begin{tabular}{|l|l|l|l|l|l|}
\hline $\mathbf{N}$ & Jenis Data & $\begin{array}{l}\text { Sumber } \\
\text { Data }\end{array}$ & Indikator & $\begin{array}{l}\text { Kriteria } \\
\text { Keberhasilan }\end{array}$ & Instrumen \\
\hline 1. & $\begin{array}{l}\text { Pengetahuan } \\
\text { tentang } \\
\text { hukum } \\
\text { perlindunga } \\
\text { n konsumen } \\
\text { Tangga } \\
\text { secara }\end{array}$ & $\begin{array}{l}\text { Pengetahuan } \\
\text { Ibu Rumah } \\
\text { Tangga Desa } \\
\text { Tianyar }\end{array}$ & $\begin{array}{l}\text { Terjadi } \\
\text { perubahan } \\
\text { yang positif } \\
\text { terhadap } \\
\text { pengetahuan } \\
\text { hukum } \\
\text { perlindungan } \\
\text { konsumen }\end{array}$ & $\begin{array}{l}\text { Tes obyektif } \\
\text { terhadap } \\
\text { hasil seleksi } \\
\text { produk di } \\
\text { lapangan }\end{array}$ \\
\hline 2. & $\begin{array}{l}\text { Pengetahuan } \\
\text { tentang } \\
\text { syarat-syarat } \\
\text { standarisasi } \\
\text { kelayakan } \\
\text { produk } \\
\text { menurut UU. } \\
\text { No 8 Tahun } \\
\text { 1999 }\end{array}$ & Ibu Rumah & $\begin{array}{l}\text { Pengetahuan } \\
\text { Thu Rumah } \\
\text { Tangga Desa } \\
\text { Tianyar }\end{array}$ & $\begin{array}{l}\text { Terjadinya } \\
\text { perubahan } \\
\text { yang positif } \\
\text { pengetahuan } \\
\text { Ibu Rumah } \\
\text { Tangga tentang } \\
\text { syarat-syarat } \\
\text { standarisasi } \\
\text { kelayakan } \\
\text { produk }\end{array}$ & $\begin{array}{l}\text { Pedoman } \\
\text { wawancara } \\
\text { observasi }\end{array}$ \\
\hline
\end{tabular}

Peran Ibu rumah tangga di Desa Tianyar yang akan melangsung pembelian setiap jenis produk untuk kebutuhan sehari-hari. Dipilihnya sasaran Ibu rumah tangga, selain merupakan kelompok masyarakat yang rutinitasnya identik dengan keterlibatannya dalam proses pembelian barang untuk dikonsumsi, juga merupakan masyarakat yang 
memiliki tingkat produktivitas mobilisasi yang tinggi dalam penyebar luasan informasi, terutama yang berkaitan dengan UU Perlindungan Konsumen.

Alternatif ini dipilih berdasarkan hasil analisa di lapangan untuk menganalisa sistem tata niaga dapat merujuk beberapa:
1) Pendekatan alternatif dalam kegiatan sosialisasi UU Perlindungan Konsumen di atas, diantaranya yaitu:

a) Pendekatan fungsi (the fuctional approach), yang terdiri dari fungsi pertukaran (pembelian dan penjualan), fungsi fisis (penyimapanan, pengolahan, dan pengangkutan) dan fungsi fasilitas (standarisasi pembiayaan, resiko, dan market intelligence).

b) Pendekatan kelembagaan (the institutional approach), yang terdiri dari pedagang perantara (merchant midllemen) yaitu pedagang grosir dan pedagang eceran, agent midllemen (broker dan commisioner), pedagang spekulatif, pengolah (processors dan manufacturing) dan organisasi yang memberikan fasilitas tataniaga.

c) Pendekatan perilaku, pendekatan yang terakhir ini merupakan kelengkapan antara pendekatan fungsi dan kelembagaan, yaitu menganalisis aktifitas-aktifitas yang ada dalam proses tataniaga seperti perubahan dan perilaku lembaga tataniaga dan kombinasi fungsi-fungsi (Hidayah, 2007 : 27).

Berdasarkan rujukan pendekatan di atas, melalui kegiatan penelitian ini diharapkan terjadi peningkatan

pemahaman
Perlindungan Konsumen Ibu rumah tangga dan tetap menjaga hubungan yang sinergis antara produsen, Ibu rumah tangga sebagai konsumen dengan memahami frame work masing-masing dan dapat bekerjasama untuk dapat menghasilkan produk yang layak konsumsi.

Hasil temuan Ibu rumah tangga di lapangan bahwa praktek kecurangan produsen yang terjadi dilakukan dengan tanpa mempertimbangkan persyaratan UU No. 8 Tahun 1999 tentang Perlindungan Konsumen disebabkan karena beberapa hal, yaitu:

(1) sebagian besar masyarakat tidak mengetahui dan memahami aturan kelayakan konsumsi dan penjaminan keselamatan bagi konsumen dari perilaku tidak sehat produsen yang menyimpang dari perlindungan konsumen yaitu UU No. 8 Tahun 1999,

(2) belum ada sanksi tegas terhadap pelaku produksi yang tidak memenuhi persyaratan kelayakan produksi sebagaimana yang disyaratkan dalam UU No. 8 Tahun 1999 tentang Perlindungan Konsumen,

(3) belum dipahaminya langgahlangkah pengaduan dan pelaporan dari warga apabila menjumpai peredaran barang tidak layak konsumsi,

(4) Kejelian warga masyarakat dalam menyeleksi jenis produk yang beredar belum mampu selektif dalam menentukan pilihan;

(5) warga masyarakat memiliki kecenderungan dengan kemudahan dari penawaran promo dengan harga miring tanpa mempertimbangkan tingkat kualitas produk yang 
belum memenuhi standar kelayakan konsumsi.

Hasil evaluasi tidak lanjut juga terekam, beberapa manfaat praktis yang diperoleh oleh Ibu rumah tangga Desa Tianyar Kecamatan Kubu melalui pengembangan peran sebagai hasil tindak lanjut program sosialisasi UU No. 8 Tahun 1999 tentang Perlindungan Konsumen, yaitu:

(1) mereka mendapatkan informasi yang jelas dan utuh mengenai hakekat penjaminan keselamatan konsumen dalam substansi UU, makna perlindungan konsumen, dan syarat-syarat perlindungan konsumen dengan menyeleksi kelayakan standarisasi produk sesuai dengan UU No. 8 Tahun 1999 tentang Perlindungan Konsumen,

(2) Ibu rumah tangga yang menjadi peserta pelatihan memperoleh gambaran yang jelas mengenai syarat-syarat kelayakan standarisasi produk yang layak dikonsumsi, termasuk syaratsyarat perlindungan konsumen yang selama ini banyak dilangsungkan tidak sesuai dengan asasnya karena wawasan konsumen masih minim

(3) Peserta pelatihan juga mendapatkan gambaran yang jelas mengenai status dan kedudukan konsumen dengan jaminan UU dan implikasi hukumnya bagi praktik kecurangan peredaran produk yang tidak sah, dan

(4) Ibu rumah tangga memperoleh pengetahuan yang jelas mengenai proses dan prosedur pengaduan dan pelaporan apabila menjumpai temuan terjadi praktek kecurangan produsen dalam memasarkan barang yang tidak memenuhi syarat-syarat sebagaimana yang diatur dalam UU No. 8 Tahun 1999 tentang Perlindungan Konsumen.

\section{Simpulan}

Berdasarkan hasil penelitian terhadap peran Ibu rumah tangga dalam perlindungan konsumen di Desa Tianyar Kecamatan Kubu, Kabupaten Karangasem dapat ditarik beberapa simpulan, yaitu sebagai berikut :

1. Sasaran yang dipilih dan dipandang cukup visibel Ibu rumah tangga di Desa Tianyar Kecamatan Kubu Kabupaten Karangasem, adapun rasionalnya adalah:

(a) Ibu rumah tangga merupakan kelompok masyarakat yang akan melangsungkan transaksi pembelian produk barang untuk konsumsi kebutuhan kehidupan dalam rumah tangga,

(b) Ibu rumah tangga merupakan media penyebarluasan berbagai informasi yang sangat efektif, mengingat mobilitas sosialnya yang sangat tinggi, untuk membina dan mengarahkan putera-puteri dan kepala rumah tangga untu menyeleksi secara selektif setiap jenis produk yang beredar di pasaran dan

(c) Ibu rumah tangga disinyalir akan mampu menjadi penggerak proses tranformasi sosial masyarakat desa Tianyar yang simbolik dengan perlindungan konsumen.

2. Pelaksanaan peran pasca sosialisasi juga terekam dengan kejelian Ibu rumah tangga dalam mengidentifikasi permasalahan perlindungan konsumen yang belum optimal, bahwa peredaran produk palsu atau oplosan yang banyak dikonsumsi oleh masyarakat Desa Tianyar Kecamatan Kubu lebih 
banyak hanya dilakukan berdasarkan tanpa memeperhatikan kelayakan kemasan, standarisasi B.POM, batas waktu kelayakan konsumsi, terdapat tidaknya jenis kandungan bahan kimia berbahaya dan penggunaan zat pewarna makanan yang layak untuk produk makanan.

3. Upaya penanggulangan masalah perlindungan konsumen oleh Ibu rumah tangga analisa kajian penelitian menunjukkan bahwa dapat dipengaruhi oleh tingkat ketepatan dalam melakukan seleksi produk konsumsi kebutuhan. Dengan kualitas sumber daya manusia di Desa Tianyar Kecamatan Kubu Kabupaten Karangasem Propinsi Bali adalah berhasil meningkatkan pengetahuan dan wawasan Ibu rumah tangga dalam memahami hukum perlindungan konsumen, syarat-syarat perlindungan konsumen, asas perlindungan konsumen, dan kelayakan standarisasi produk yang akan dijadikan sebagai dasar acuan bagi mereka untuk melangsungkan aktifitas produksi.

\section{Daftar Pustaka}

Abdi Darwis. 2010. Hak Konsumen Untuk Mendapat Perlindungan Hukum Dalam Industri Perumahan Di Kota Tangerang. Tesis. Program Studi Magister Kenotariatan Program Pasca Sarjana Universitas Diponegoro Semarang.

Kurniasih, D. 2006. Pengaruh Daya Dukung Lahan dan Faktor Sosial Ekonomi Terhadap Perilaku Petani Dalam Konservasi Lahan Pertanian Di Kabupaten Kulon Progo. Yogyakarta:Program Studi Ekonomi
Berdasarkan penelitian yang telah dilaksanakan dengan sasaran peran Ibu rumah tangga di Desa Tianyar Kecamatan Kubu, ada beberapa saran yang layak dipertimbangkan, yaitu :

1. Bagi Ibu rumah tangga sebagai informan kunci penyebarluasan informasi di desa Tianyar, hendaknya mampu memberikan sosialisasi bagi masyarakat lainnya tentang pentingnya syarat-syarat perlindungan konsumen termasuk juga memberikan masukan dan koreksi terhadap praktek kecurangan produsen yang telah banyak merugikan konsumen.

2. Bagi pihak terkait, hendaknya memberikan sanksi yang tegas, bagi produsen yang terbukti melakukan pelanggaran terhadap syarat-syarat perlindungan konsumen yang ditentukan dalam UU No. 8 Tahun 1999, sehingga dapat memberikan sanksi fisik dan moral yang diharapkan berdampak bagi efek jera bagi pelaku pelanggaran.

Hidayah, N. 2007. Analisis Usaha dan Pemasaran Susu Sapi Peternak Mandiri Anggota Koperasi Susu Warga Mulya di Yogyakarta. Yogyakarta: Program Studi Ekonomi Pertanian, Jurusan Ilmu-Ilmu Pertanian, UGM.

Keraf, Sonny. 1998. Etika Bisnis, Tuntutan dan Relevansinya. Yogyakarta: Kanisius.

Pemerintah Desa Tianyar. 2011. Data Situasi Fisik dan Non-Fisik Desa Dinas Tianyar Timur. Karangasem: Pemdes Tianyar.

Setiawan, W. A. 2005. Prospek dan Pertanian Indonesia di Era Globalisasi. Jakarta: PT.Agricon. 
Krisanto, Y. A. 2008. Dampak Penerapan Hukum Persaingan Usaha Bagi Perlindungan Konsumen. Jurnal Hukum Bisnis Volume 27 No.2 Tahun 2008: Yayasan Pengembangan Hukum Bisnis.

Negara RI. Undang-Undang Dasar Negara Republik Indonesia 1945. (Lembaran Negara RI Tahun 1959 Nomor 75).

Negara RI. Undang-Undang Nomor 32 Tahun 2004 tentang Pemerintah Daerah. (Lembaran Negara RI Tahun 2004 Nomor 125, TLN Nomor 4437).

Negara RI. Undang Undang No. 8 Tahun 1999 Tentang Perlindungan Konsumen. (Lembaran Negara Republik Indonesia tahun 1999 No. 42 Tambahan lembaran Negara Republik Indonesia No. 3821).

Negara RI. Undang Undang No. 5 tahun 1999 Tentang Larangan Praktek Monopoli dan Persaingan Usaha Usaha Tidak Sehat.

Negara RI. Undang Undang No. 30 Tahun 1999 Tentang Arbritase dan Alternatif Penyelesian Sengketa.

Negara RI. Peraturan Pemerintah No. 58 Tahun 2001 tentang Pembinaan Pengawasan dan Penyelenggaraan Perlindungan Konsumen.

Negara RI. Surat Edaran Dirjen Perdagangan Dalam Negeri No. 235/DJPDN/VII/2001 Tentang Penangan pengaduan konsumen yang ditujukan kepada Seluruh dinas Indag Prop/Kab/Kota.

Negara RI. Surat Edaran Direktur Jenderal Perdagangan Dalam Negeri No. 795/DJPDN/SE/12/2005 tentang Pedoman Pelayanan Pengaduan Konsumen.

www.google.com Semardi. UU Perlindungan Konsumen. Diakses hari Rabu, tanggal 29 Agustus 2012, pukul 14.45 Wita. www.google.com. Wikipedia. 2009. Konsumen. Diakses Rabu, tanggal 29 Agustus 2012, pukul 14.00 Wita. 